\title{
Comparison of Sexual Satisfactions and Attachment Styles of Patients with Bipolar I Disorder, Borderline Personality Disorder and Healthy Controls
}

\author{
Tolga ŞAKAR ${ }^{1}$, Ayhan ÇAKICI EŞ²
}

\begin{abstract}
The aim of this study is to analyze sexual dissatisfaction and attachment styles of patients with Bipolar and Borderline pathologies. The sample includes 25 Bipolar and 25 borderline participants. 50 participants of control group were selected among nonpsychiatric patients at internal medicine service from Uşak State hospital. In the analyses of data One-Way ANOVA and Pearson Correlation were used. BPD and BD were determined as based on SCID 2 and DSM 5 in Uşak State Hospital by psychiatrist. Golombok-Rust Sexual Satisfaction Inventory (GRISS) were used to determine sexual dissatisfactions and Attachment Styles were evaluated by Relationship Scales Questionnaire (RSQ). It was found that there is a positive correlation between insecure attachments and individuals with BD and BPD. Findings indicated stronger positive correlation between insecure attachments and sexual dissatisfaction in individuals with control group than to individuals with BD and BPD. This study showed that BD and BPD may have similarity in terms of sexual dissatisfaction and insecure attachment styles. However, future studies may be examine attack as well as euthymic periods. Studies should not limited as heterosexual in the future studies. Thus, sexual dissatisfaction of individuals could be examined in more controlled conditions to avoid risks.
\end{abstract}

Keywords: Bipolar Disorder, Borderline Personality Disorder, Attacment, Sexual Satisfaction

\section{Bipolar Bozukluk, Borderline Kişilik Bozukluğu ve Sağlıklı Kontroller Olan Hastaların Bağlanma Stilleri ve Cinsel Doyumlarının Karşılaştırılması}

Özet: Bu çalışmanın amacı bipolar ve Borderline patolojileri olan hastaların cinsel doyumlarını ve bağlanma stillerini analiz etmektir. Bu çalışmaya bipolar grup olarak seçilen 25 katılımcı ve Borderline grubu olarak seçilen 25 katılımcı dahil edildi. Uşak Devlet Hastanesi'nden iç hastalıkları servisinden psikiyatri dışı hastalar arasından 50 kontrol grubu katılımcısı seçildi. Tek Yönlü ANOVA ve Pearson Korelasyonu istatistiksel olarak kullanıldı. BPD ve BD Uşak Devlet Hastanesinde psikiyatrist tarafından SCID 2 ve DSM 5 esas alınarak belirlendi. Cinsel doyum, Golombok-Rust cinsel doyum envanteri (GRISS) ile değerlendirildi. Bağlanma Stilleri, İlişki Ölçekleri Anketi (RSQ) ile değerlendirildi. Bulgular, güvensiz bağlanmalar ile Bipolar Bozukluk ve Sınır Kişilik Bozukluğu olan bireyler arasında kontrol grubuna göre daha fazla pozitif korelasyon tespit edildiğini göstermiştir. Genel olarak, bulgular kontrol grubu olan bireylerde güvensiz bağlanma ile cinsel doyum arasında Bipolar Bozukluk ve Borderline Kişilik Bozukluğu olan bireylerden daha fazla pozitif korelasyon tespit edildiğini göstermiştir. Bu çalışma Bipolar Bozukluk ve Borderline Kişilik Bozukluğunun cinsel doyum ve güvensiz bağlanma stilleri açısından benzerlik gösterebileceğini göstermiştir. Gelecekteki çalışmalarda heteroseksüel katılımcılarla sınırlı olmamalıdır. Böylece, kişilerin cinsel memnuniyetsizlikleri daha kontrollü ve daha az riskli koşullarda spesifik olarak incelenebilir.

Anahtar Kelimeler: Bipolar Bozukluk, Sınır Kişilik Bozukluğu, Bağlanma, Cinsel doyum.

${ }^{1}$ Exp. Psychologist. Tolga Şakar, Şakar Psychological Counseling Centre, Special Öztan Hospital Uşak-Turk

${ }^{2}$ Assist. Prof. Ayhan Çakıcı Eş, Near East University, Department of Psychological Counseling and Guidance.

Address of correspondence/ Yazışma adresi: Tolga Şakar, Şakar Psikolojik Danışma Merkezi, Özel Öztan Hastanesi, UşakTürkiye. Email: sakartolga387@gmail.com

Date of received/ Geliş Tarihi: 23.04.2019, Date of acceptance/ Kabul Tarihi: 30.04.2019

Citing/ Referans Gösterimi: Şakar, T., Çakıcı Eş, A., (2019). Comparison of Sexual Satisfactions and Attachment Styles of Patients with Bipolar I Disorder, Borderline Personality Disorder and Healthy Controls. Cyprus Turkish Journal of

Psychiatry \& Psychology, 1(1): 42-49 doi:10.35365/ctjpp.19.1.05 


\section{Introduction}

Bipolar Disorder (BD) and Borderline Personality Disorder (BPD) explained as a recurrent fluctuated mood periods such as impulsive sexual risky behaviors and desires (Eroğlu, 2010). Patients with rapid-cycling mood disorder may have personality disorder, also BD was a dual-form madness. Symptoms of personality disorder seen in \%48 of patients with BD (Yüksel, Kurt, Tüzer ve Göka, 2004). Acording to another study, depressive and manic symptoms weren't opposite poles (Johnson, Morriss, Scott, Paykel, Kinderman KolamunnageDona \& Bentall, 2011). The relations of individuals with BPD could been inconsistent due to self and object relations related with splittings in childhood. Also, family history, response to treatment and progress of treatment show us that, BPD and mood disorders were associated with each other (Öztürk \& Uluşahin, 2001). BPD may overlaps with BD and major depressive disorder due to similarities with mood disorders (Biskin \& Paris, 2012).

BPD was related with irregular attachment styles. According to Young's schema model, patients with BPD may have abandonment beliefs due to changeable mood (Beck, 2008). Individuals with BPD may show cyclical tides such as opposite moods as omnipotent or depressive due to constant instability, inconsistently self-images and fluxional stormy affective intensity. They may have irregular sexual anxiety related with hunger to objects due to cannot tolerate the loneliness, so they may have "impulsive sexual behavior" to avoid real or imagined abandonment. Thus, they may tend to be highly dependent to others. They have no object permanence due to an inability to separationindividuation phase, so they may show frantic sexual effort to avoid loneliness (Köroğlu, 2011).

According to Masterson's (2008) BPD approach, real self was sacrificed by false self, so intrapsychic functioning is divided. Child wants return to back to caregivers due to need for praise and approval to ensure "libidinal refueling" despite try to be independent in rapprochement subphase of separation-individuation. If caregiver has only bad or only good attitude to child, then other humans may have completely good or fatally bad meaning for the child (Aydın, 2010).

According to attachment theory of Bowlby and Ainsworth, the quality of life was determined to lifelong relationships by nature of relationships at earlier life. Individuals with preoccupied attachment want acceptance by others due to need of self-worthiness. Individuals with dismissing attachment do not trust to others due to hostility despite overconfidence to themselves, so they may have emotional distance and low anxiety during to relation. Individuals with a fearful attachment, evaluate negative themselves as well as others due to fear of rejection (Çapan, 2009). Secure attachment is related with strong bond of sense of basic trust. However, if problem was occurred during this time, protest, despair and detachment may occur (Göçener, 2010). Bowlby's concept of attachment is related with deep emotional bond due to needs for belonging and trust, so future close relationships is depended to the first relation between newborn and caregiver (Kırımer, Sümer \& Akça, 2014).

The most important factors for attachment are continued proximity, secure base and safe haven (Özer, 2011). Secure attachment could disrupted by mood disorders, so insecure attachment style considered as a predictor of psychopathology in the later stages of life (Kesebir, Kavzoğlu \& Üstündağ, 2011). Individuals with secure attachment have no fear of abandonment due to self-esteem, so attachment styles may give direction to romantic relationship (İlhan, Özdemir 2012).

BPD may appropriate to darker or the less stable state than BD 2, as it continuously tides between depression or irritable hypomania and cyclothymic temperament (Çalışır, 2008). According to another research, BPD may included within Bipolar spectrum due to common neurobiological, neuroimaging and neuroscientific findings, similar emotional instability and impulsivity (Agius, Lee, Gardner\& Wotherspoon, 2012). It is known that reported that $12-23 \%$ of patients with $\mathrm{BD} 2$ involved BPD criterias, so "Spectrum" should be considered as a more wide range as well as similarities about mood instability, impulsivity and developmental stages (Elisei, Anastasi \& Verdolini, 2012). On the other hand, completely common etiology could not yet defined among BPD and BD (Paris, Gunderson \& Weinberg., 2007). Many BPD conditions may seen as manic depression (Stone, 1979).

Ratio of self-demolition of mood disorders were determined highly over as 60\% just like BPD (Uğur, Tamam, Özpoyraz \& Demirkol, 2012). According to some researchers, both of BD and BPD may overlap as phenomenological common features, impulsivity, comorbidity, treatment responses, so BDP must be involve in axis I disorders. Acording to Paris and friends (2007), BPD patients had ratio of BD1 as average range of $9.2 \%$ and ratio of $\mathrm{BD} 2$ as average range of $10.7 \%$. Also, comorbidity rates of cyclothymia and BPD were $62 \%$. According to Akiskal, BPD was defined as mild or soft BD (Belli, Ural \& Akbudak, 2013).

According to Otto-Salaj and Stevenson, patients with BD may live unprotected risky random sexual intercourses with extreme sexual desires during manic attack (Karadağ, Hariri \& Kenar, 2004). Uncontrolled sexual activity may good part of selfexpression during mania, so this situation may cause conflicts within relationships (McCandless \& 
Sladen, 2003). Hypersexuality is a common symptom of mania-hypomania for children and adolescents with $\mathrm{BD}$, so the girls with $\mathrm{BD}$ had vulnerability due to hypersexuality (Basco \& Celisde Hoyos, 2012). On the other hand, individuals with BPD may have emptiness or abandonment feelings, unstable self image, emotional instability and impulsivity. So this situation may reflect as conflict into relationships (Valentiner, Hiraoka \& Skowronski, 2014). Sexual rarity was reported during to depression, so sexual problems may be dependent on the changes related with BD (Lam, Donaldson, Brown \& Malliaris, 2005). Sexual dysfunction of women with BPD was determined higher than to healthy women in another study (Schulte-Herbrüggen, Ahlers, Kronsbein, Rüter, Bahri, Vater \& Roepke, 2009). It is also known that trauma was related with BPD. Espacially sexual abuse was the most effective trauma for BPD (Sansone, Chu \& Wiederman, 2001). Sexuality was a tool to prevented chronic emptiness, abandonment, anxiety, perversions, and ambivalence feelings due to insecure attachment (Bouchard, Godbout, \& Sabourin, 2009).

The aim of this study is investigating the sexual satisfactions of three different groups which are $\mathrm{BD}, \mathrm{BPD}$ and non-psychiatric control group according to their attachments styles.

\section{Method}

This study was conducted in Uşak, Turkey, between March and July 2015. It included 100 Turkish participants (25 with BD, 25 with BPD, 50 with non-psychiatric). The participants' age varied between 18-50 years. Participation to the study was as voluntary and the participants were selected through random sampling method. The participation started in Uşak State hospital. Informed consent form was completed by the participants before the study. The questionnaire consist of, Socio-demographic Information Form, Relationship Scales Questionnaire (RSQ) and the Golombok-Rust Inventory of Sexual Satisfaction (GRISS). Participants completed the questionnaires approximately in 20 minutes. Ethics committee approval were available.
Socio-demographic form: Information Form and Informed Consent were given to participants, thenSocio-demographic form given that include questionsregarding age, gender, education level, earnings, job, marital status.

Golombok-Rust Inventory of Sexual Satisfaction (GRISS): Golombok-Rust Inventory of Sexual Satisfaction, which was developed by Rust and Golombok includes 28 items. The aim of this scale is to measure the quality of sexual relationship and the presence and severity of both male and female sexual problems. There are two separate forms for female and male participants. Five dimensions of the inventory are common for both sexes. Female version has two additional dimensions (i.e., vaginusmus and anorgasmia), also male version of the inventory has two additional dimensions (i.e., premature ejaculation and impotence). Each item is rated on a 5 point likert type scale and answers vary between "never" to "always". Higher scores indicate higher level of sexual dysfunction and lower level of sexual quality. Original scale was translated and adapted to Turkish by Tugrul andcolleagues which shows good reliability (Tuğrul, Öztan \& Kabakç1, 1993).

Relationship Scales Questionnaire (RSQ): Relationship Scales Questionnaire was developed in 1994 by Griffin and Bartholomew. Then, it was adapted into Turkishby Sumer and Gungor in 1999. There are four sub-scales aimed at measuring the adult attachment styles, such as consisting to secure, preoccupied, dismissing and fearful attachment in Relationship Scale. Relationship Scales Questionnaire are a scale to be stylish in 7th to answer the Likert-type 30 items as total for each item 1 "no not like me" and 7 "totally like me" (Sümer \& Güngör, 1999).

Statistical Analysis: All the analyses were performed by using a computer program for the multivariate statistics; Statistics Package for the Social Sciences (SPSS), version 20 for Windows. ANOVA and Pearson Correlation were made to statistical analysis. Numerical datawas compared obtained from the objective test results. 


\section{Results}

Table 1. Comparison of mean score of "Attachment Styles" than to participants with BD-BPD-Control groups $(\mathrm{p}<0.05)$

\begin{tabular}{|c|c|c|c|c|}
\hline \multirow{2}{*}{$\begin{array}{l}\text { BD Group } \\
\text { Attachments }\end{array}$} & \multicolumn{2}{|c|}{ Women dissatisfaction } & \multicolumn{2}{|c|}{ Man dissatisfaction } \\
\hline & $\mathrm{r}$ & (p) & $\mathrm{r}$ & (p) \\
\hline Secure & -0.027 & 0.897 & -0.031 & 0.883 \\
\hline Preoccupied & 0.196 & 0.347 & 0.198 & 0.344 \\
\hline Fearful & 0.247 & 0.223 & 0.096 & 0.648 \\
\hline Dismissing & 0.333 & 0.104 & $0.398 *$ & 0.049 \\
\hline \multicolumn{5}{|l|}{ BPD Group } \\
\hline Secure & -0.067 & 0.750 & 0.231 & 0.267 \\
\hline Preoccupied & -0.001 & 0.997 & 0.003 & 0.997 \\
\hline Fearful & 0.213 & 0.306 & -0.068 & 0.745 \\
\hline Dismissing & 0.208 & 0.319 & 0.018 & 0.933 \\
\hline \multicolumn{5}{|l|}{ Control } \\
\hline Secure & $-0.308 *$ & 0.029 & -0.019 & 0.898 \\
\hline Preoccupied & $0.680 * *$ & 0.000 & $0.371 * *$ & 0.008 \\
\hline Fearful & $0.639 * *$ & 0.000 & $0.318 * *$ & 0.024 \\
\hline Dismissing & $0.516 * *$ & 0.000 & 0.155 & 0.283 \\
\hline \multicolumn{5}{|c|}{$\begin{array}{ll}\text { Participants with BD-BPD-Control group were } & \text { had less mean scores to preoccupied-fearfull- } \\
\text { compared with secure and insecure attachment } & \text { dismissing attachments subscales than BD and BPD } \\
\text { subscales of RSQ by One-Way ANOWA. Control } & \text { groups. As a result, individuals with diagnose of } \\
\text { group had higher mean scores to secure attachment } & \text { BD and BPD had many similar mean scores related } \\
\text { subscales than BD and BPD groups. Control group } & \text { with attachment styles than to control groups }\end{array}$} \\
\hline
\end{tabular}

Table2. Correlations between Attachment Styles (RSQ) and Man-Women Dissatisfaction (GRISS) than to patients with BD-BPD-Control groups:

\begin{tabular}{|c|c|c|c|}
\hline Secure Attachment & $\mathrm{N}$ & $\mathrm{m} \pm \mathrm{sd}$ & $\mathrm{F}(\mathrm{p})$ \\
\hline Group with BD & 25 & $24.56 \pm 5.64$ & \multirow{4}{*}{$\begin{array}{l}56.26 \\
(0.000)^{*}\end{array}$} \\
\hline Group with BPD & 25 & $23.36 \pm 4.79$ & \\
\hline Control & 50 & $34.64 \pm 4.86$ & \\
\hline Preoccupied A. & $\mathrm{N}$ & & \\
\hline Group with BD & 25 & $26.52 \pm 6.02$ & \multirow{3}{*}{$\begin{array}{l}35.75 \\
(0.000)^{*}\end{array}$} \\
\hline Group with BPD & 25 & $27.12 \pm 4.40$ & \\
\hline Control & 50 & $18.54 \pm 4.51$ & \\
\hline Fearful A. & $\mathrm{N}$ & & \\
\hline Group with BD & 25 & $49.00 \pm 7.33$ & \multirow{2}{*}{$\begin{array}{l}153.00 \\
(0.000)^{*}\end{array}$} \\
\hline Group with BPD & 25 & $47.32 \pm 7.30$ & \\
\hline Control & 50 & $21.48 \pm 7.93$ & \multirow{5}{*}{$\begin{array}{l}80.93 \\
(0.000)^{*}\end{array}$} \\
\hline Dismissing A. & $\mathrm{N}$ & & \\
\hline Group with BD & 25 & $41.48 \pm 5.58$ & \\
\hline Group with BPD & 25 & $42.48 \pm 4.35$ & \\
\hline Control & 50 & $27.32 \pm 4.42$ & \\
\hline $\begin{array}{l}\text { In the present study, correlation between attachment } \\
\text { styles and man-woman dissatisfaction examined by } \\
\text { Pearson Correlation Analysis. There were middle } \\
\text { level positive correlations between men- } \\
\text { dissatisfaction and dismissing attahment to patients } \\
\text { with BD. There weren't any significant correlations } \\
\text { between especially; women-dissatisfaction and } \\
\text { secure-preoccupied-fearful-dismissing attachments, }\end{array}$ & & \multicolumn{2}{|c|}{$\begin{array}{l}\text { men dissatisfaction and secure-preoccupied-fearful } \\
\text { attachments to patients with BD and BPD. } \\
\text { There were middle level negative correlations } \\
\text { between women-dissatisfaction and secure } \\
\text { attachment to participants with Control group. } \\
\text { There were high level positive correlations between } \\
\text { women-dissatisfaction and fearful-preoccupied }\end{array}$} \\
\hline
\end{tabular}


attachments in participants to participants with Control group. There were middle level positive correlations between "men-dissatisfaction and fearful-preoccupied attachments" "womendissatisfaction and dismissing attachment" to participants with Control group. There weren't any significant correlations between man-dissatisfaction and secure-dismissing attachments to participants with Control group.

\section{Discussion}

In this study, sexual satisfaction was compared between BD, BPD and non psychiatric participants. The most important features of patients with BPD are intensity of the affectives and fluxional behaviors (Köroğlu, 2011). Also, the unsafe sex practices were one of the most commonly symptoms of Borderline patients (Lloyd, Raymond, Miner \& Coleman, 2007). Sexuality often used as a tool as to prevent chronic feelings of emptiness and abandonment to appease of anxiety in this group of women with BPD (Bouchard, Godbout \& Sabourin, 2009). On the other hand, according to McCandles and Sladen, sexual activity can be a pleasurable and very important part of self-expression during to manic episode of BD. However, normally, bipolar patients may have lowest sexuality during to euthymic period than the manic phase. This research was conducted to patients within that euthymic phase, so sexuality of Bipolar and Borderline patients may be lowest. Also, Bipolar individual's living sexual indiscretions as randomly and uncontrolled during Manic episode, so then may cause conflicts in his relationships (McCandles \& Sladen, 2003).

According to this study, extreme sexual dissatisfaction does not mean to be higher level of sexual actions. Even, findings may quite surprisingly. Normally, according to the symptomatology, Bipolar and Borderline people may have extreme sexuality as action. Therefore findings may be seen just like misleading. Whereas, sexual dissatisfaction may be a stigma for Bipolar and Borderline patients. Bipolar and Borderline patients might wants to hide own sexual dissatisfaction despite extreme sexual actions. Especially, Borderline patients may have prejudice to sexuality. Because, according to studies of Sebastien Bouchard; there were compared as a broad spectrum to sexual postures and behaviors of women with BPD with, women without BPD in a research conducted at Qubec province in Canada's eastern. In this study, it was investigated relationship between sexual postures and their sexual activity of women with BPD. When it was compared, women with BPD have more sexual partners than females in control group. Women in the control group have, more exceeded than $6 \%$ $(n=2)$ sexual partner to along lifetimes, women with
BPD have more exceeded than sexual partners to $50 \%(n=19)$ along lifetimes for sexual activity. In BPD group were higher to prejudice to sexuality. However, women with BPD had more sexual partners Also, according to studies of Sebastien Bouchard, women with BPD overmuch feels pressure to sexual intercourse. Therefore, women with BPD have more sexual partners than women without BPD, so they feels to more pressure for sex in themselves (Bouchard, Godbout \& Sabouring, 2009). According to another studies of Karadağ, patients with BD live erotomania and impulse control difficulties during manic attack, they may enter into the indiscriminate sexual intercourse and also they have inability to resist forced unwanted sexual relationship (Karadağ, Hariri \& Kenar, 2004).

As a result, in this study, sexual dissatisfaction and attachment styles of individuals with BD and BPD have most similar than non psychiatric individuals, so its looks like this situation may be a Dilemma. Because, individuals with BD and BPD may have extreme sexual actions. However, Patients with BD and BPD selected for this study in euthymic period. Extreme and dissatisfacted sexuality was minimized in euthymic period due to some causes like this drug use. Therefore, it may occurs better sexual satisfaction intended to sexual relations in euthymic period than to other periods. Therefore, results are not a dilemma. On the other hand individuals with BPD and BD had most similar insecure attachment than to non psychiatric individuals. This situation may related with inhibited euphoric and omnipotent attachment desires in non euthymic period. According to results of this study, patients with $\mathrm{BD}$ and $\mathrm{BPD}$ have most insecure attachment, so non psychiatric participants have lowest insecure attachment. On the other hand, typically, people with anxious attachment representations (namely, head to engage with abandonment and rejection) tend to have sex to guarantee themselves and to attract the attention of partners (Bouchard, Godbout \& Sabourin, 2009).

According to another study, the majority of Borderline individuals have an insecure attachment style as evident with distrust of others and fear of abandonment. According to spesific studies at literature, healthy participants of control group have higher secure attachment, lower anxious, and lower preoccupied attachment scores than to patients with BD (Morriss, van der Gucht, Lancaster \& Bentail, 2009). On the other hand, patients with BPD are characterized by irregular attachment styles. Already, abandonment depression of Borderline patients were related with expression of insufficiency of object (Masterson, 2008).

According to this study, patients with BD and BPD had lowest secure attachment more different than non psychiatric participants. There were found 
statistically significant differences between especially; non psychiatric and Bipolar group, non psychiatric and Borderline group. As a result, individuals with $\mathrm{BD}$ and BPD have less secure attachment, so non psychiatric individuals have more secure attachment. Patients with BD and BPD had biggest preoccupied attachment different than non psychiatric participants. There were found statistically significant differences between especially; non psychiatric and Bipolar group, non psychiatric and Borderline group. As a result, patients with BD and BPD have bigger fearful attachment, so non psychiatric participants have less fearful attachment. Patients with BD and BPD had more fearful attachment than non psychiatric participants. There were found statistically significant differences between especially; non psychiatric and bipolar group, non psychiatric participants and Borderline group. As a result, Patients with BD and BPD have bigger fearful attachment, so non psychiatric participantshave less fearful attachment. Patients with BD and BPD had biggest dismissing attachment different than non psychiatric participants. There were found statistically significant differences between especially non psychiatric and bipolar group, nonpsychiatric and borderline group. As a result, Patients with BD and BPD have more dismissing attachment, so non psychiatric participants have less dismissing attachment. In this study, it was found middle level positive correlations between dissatisfaction of men and dismissing attachment in patients with BD. Namely, Bipolar men with dismissing attached may have more sexual dissatisfaction but bipolar men had sexual dissatisfacted for dismissing attahment. As a result, individuals with BD may have sense of dissatisfaction as a sexual due to dismissing attachment. Whereas, according to McCandles and Sladen in another study, sexual activity can be a pleasurable and very important part of selfexpression during to manic episode of BD (McCandles \& Sladen. 2003). Generally, it was found that there were not any significant correlations between individuals with BPD and BD as a similarly than to another individuals. According to another specific study, women with BPD is considered to had dysfunctional attitudes against sexuality, so it was detected Borderline women had more anxious attachment than to other women by regression analysis. As a result, there were found a significant between anxious attachment and suppressed feelings towards sexuality so Borderline women may have sexual ambivalence. Women with BPD may feel compelled to have sex with their partners due to anxious attachment and to appease the fear of rejection (Bouchard, Godbout \& Sabourin, 2009).

Another study related with romantic attachment styles of men with sex addicted. ANOVA revealed that sexually addicted men are more likely to relate with insecure attachment styles (Zapf, Greiner \& Carroll, 2008).

In this study, it was found middle level negative correlations between dissatisfaction of women and secure attachment in participants of Control group. Therefore, non psychiatric women with secure attached may have lowest sexual dissatisfaction. Namely, non psychiatric women with secure attached may have lowest sexual dissatisfaction problem. Because, this result show us, dissatisfaction of women decreased during to secure attahment increased, or it occurs just the opposite. It was found high level positive correlations between dissatisfaction of women and preoccupied attachment in participants of Control group. Thus, non psychiatric women with preoccupied attached may have more sexual dissatisfaction. It was found high level positive correlations between dissatisfaction of women and fearful attachment in participants of Control group. Namely, non psychiatric women with fearful attached may have more sexual dissatisfaction in this study. Acording to another study at literature, sexual satisfaction is affects to quality of life. On the other hand, discontented human not want sexual act without exciting with foreplay/touches of satisfactory. According to another study, men who answered rated experiencing pleasure as the most important factors related with fulfil partner's needs, achieve orgasm, maintain a good erection, having foreplay. Women rated having foreplay as the main factor, together with a romantic relation and to experience pleasure, fulfil partner's needs, experience sexual desire, achieve orgasm, satisfaction after sex, experience intercourse of desired length, and to maintain a good lubrication (Waldkirch, Buvat, 2007).

\section{Conclusion}

According to this study, both individuals with BPD and $\mathrm{BD}$ have similar pathologies to sexual satisfaction and attachment styles. Sexual dissatisfaction and inseccure attachments are quite unique and caotic as a suppressed behavior for a lot of people, especially Bipolar and Borderline individuals due to opposite ambivalence behaviors as a circle paradoxal contradiction. It was found that attachment styles hidden behind the sexual satisfaction in humans with Bipolar and Borderline pathologies. It was detected that sexual dissatisfaction behavior of patients with Bipolar Disorder and patients with Borderline Disorder are affected from attachment styles. Results were found similar just like expected to patients with BD and BPD in euthymic period. In individuals with bipolar and borderline pathologies were found completely similar attachment styles than non psychiatric healthy individuals. On the other hand, in generally, 
it was found correlation between attachment styles and sexual satisfaction of patients with BD and BPD than non psychiatric healthy individuals. Results might not be completely enough and specific because only heterosexual participants in euthymic episode was included to this study. However, in the future studies examine attack of patients with BD and BPD as well as euthymic periods. Also, participants should not limited as heterosexual in the future studies. Thus sexual dissatisfaction of participants could examined better. This research about sexual dissatisfaction and attachment styles in individuals with BD and BPD must be evaluate as most specific and most comprehensive for the future studies.

\section{References}

Agius, M., Lee, J., Gardner, J., \& Wotherspoon, D. (2012). Bipolar II disorder and borderline personality disorder-comorbidity or spectrum. Psychiatr Danub, 24(suppl 1), S197-201.

Aydın, M. (2010). Masterson Yaklașımında Borderline Kișilik Bozukluğunda Gelişimsel Yaklaşım. (Unpublished Master Thesis) Istanbul: İstanbul Ticaret Üniversitesi.

Basco, M. R., \& Celis-de Hoyos, C. E. (2012). Biopsychosocial model of hypersexuality in adolescent girls with bipolar disorder: strategies for intervention. Journal of child and adolescent psychiatric nursing, 25(1), 42-50.

Beck, A.T. (2008). Kişilik Bozuklukları Bilişsel Terapisi. (Çev. Yalçın, Ö. ve Akçay, N.E.). İstanbul: Litera Yayıncılık.

Belli, H., Ural, C., \& Akbudak, M. (2013). " Borderline" Kisilik Bozuklugu: Duygudurum Dengeleyicilerinin Tedavideki Yeri/Borderline personality disorder: the place of mood stabilizers in the treatment. Dusunen Adam, 26(1), 72.

Biskin, R. S., \& Paris, J. (2012). Diagnosing borderline personality disorder. CMAJ, 184(16), 1789-1794.

Bouchard, S., Godbout, N., \& Sabourin, S. (2009). Sexual attitudes and activities in women with borderline personality disorder involved in romantic relationships. Journal of Sex \& Marital Therapy, 35(2), 106-121.

Çalışır, M. (2008). Sınırda Kişilik Bozukluğu Aslında Bir Bipolar Spektrum Bozukluğu mudur?. Klinik Psikiyatri Dergisi, 11(3).

Çapan, B. E. (2009). Öğretmen adaylarinin kişilerarasi ilişkileri ve bağlanma stilleri arasindaki ilişki. Anadolu University Journal of Social Sciences, 9(2).

Corona, G., Petrone, L., Mannucci, E., Magini, A., Lotti, F., Ricca, V., ... \& Maggi, M. (2006). Assessment of the relational factor in male patients consulting for sexual dysfunction: the concept of couple sexual dysfunction. Journal of andrology, 27(6), 795-801.

Elisei, S., Anastasi, S., \& Verdolini, N. (2012). The continuum between bipolar disorder and borderline personality disorder. Psychiatr Danub, 24(suppl 1), S143-S146.

Eroğlu, Z. Meliha. "Bipolar Bozuklukta Koruyucu Sağaltım". (Unpublished Master Thesis) Çukurova Üniversitesi Tıp Fakültesi Psikiyatri Anabilim Dalı, 2(2):206-236 2010.

Göçener, D. (2010). Üniversite öğrencilerinin güvenli bağlanma düzeyleri ile kișilerarası ilisski tarzları arasındaki ilişkiler. (Unpublished Master Thesis). Ankara: Ankara Üniversitesi Sosyal Bilimler Enstitüsü.

İlhan, T. \& Özdemir, Y. (2012). Beliren Yetişkinlerde Yaş, Cinsiyet ve Bağlanma Stillerinin Kimlik Statüleri Üzerindeki Yordayıcı Rolü. Dicle Üniversitesi Ziya Gökalp Eğitim Fakültesi Dergisi. (19) 227-241.

Karadağ, F., Hariri, A. G., \& Kenar, J. (2004). Şizofreni ve İki Uçlu Duygudurum Bozukluğu Olan Hastalarda Cinsel Yolla Bulaşan Hastalıklara Karşı Farkındalık ve Riskli Cinsel Davranışlar. Klinik Psikiyatri Dergisi, 7(1), 17-25.
Kesebir, S., Kavzoğlu, S. Ö., \& Üstündağ, M. F. (2011). Bağlanma ve psikopatoloji. Psikiyatride Guncel YaklasimlarCurrent Approaches in Psychiatry, 3(2), 321-342.

Kırımer, F., Sümer, N., \& Akça, E. (2014). Orta çocuklukta anneye kaygılı ve kaçınan bağlanma: Yakın İlişkilerde Yaşantılar Envanteri-II Orta Cocukluk Dönemi Ölçeğinin Türkçeye uyarlanması. Türk Psikoloji Yazıları, 17(33), 45-57.

Köroğlu, E. (2011). Kişilik Bozuklukları. Ankara: Hekimler Yayın Birliği.

Lam, D., Donaldson, C., Brown, Y., \& Malliaris, Y. (2005). Burden and marital and sexual satisfaction in the partners of bipolar patients. Bipolar disorders, 7(5), 431-440.

Lloyd, M., Raymond, N. C., Miner, M. H., \& Coleman, E. (2007). Borderline personality traits in individuals with compulsive sexual behavior. Sexual Addiction \& Compulsivity, 14(3), 187-206.

Masterson. F.J. (2008). Kișilik Bozuklukları. (Cev. Taylan Bozkurt, B. \& Soylu, T.V.) Istanbul: Litera Yayıncılık.

McCandless, F., \& Sladen, C. (2003). Sexual health and women with bipolar disorder. Journal of Advanced Nursing, 44(1), 4248.

Morriss, R. K., van der Gucht, E., Lancaster, G., \& Bentall, R. P. (2009). Adult attachment in bipolar 1 disorder. Psychology and Psychotherapy: theory, research and practice, 82(3), 267-277.

Özer, M. (2011). Suçluluk-utanç, bağlanma, algılanan ebeveynlik (anne) tarzı ve psikolojik belirtiler arasındaki ilişkiler. (Unpublished master thesis), Savunma Bilimleri Enstitüsü, Kara Harp Okulu, Ankara.

Öztürk, M. O. \& Uluşahin, A. (2011). Ruh Sağllğı Ve Bozuklukları 1. Ankara: Nobel Tip.

Paris, J., Gunderson, J., \& Weinberg, I. (2007). The interface between borderline personality disorder and bipolar spectrum disorders. Comprehensive psychiatry, 48(2), 145-154.

Sansone, R. A., Chu, J. W., \& Wiederman, M. W. (2011). Sexual behaviour and borderline personality disorder among female psychiatric inpatients. International journal of psychiatry in clinical practice, 15(1), 69-73.

Schulte-Herbrüggen, O., Ahlers, C. J., Kronsbein, J. M., Rüter, A., Bahri, S., Vater, A., \& Roepke, S. (2009). Impaired sexual function in patients with borderline personality disorder is determined by history of sexual abuse. The journal of sexual medicine, 6(12), 3356-3363.

Stone, M. H. (1979). Assessing vulnerability to schizophrenia or manic-depression in borderline states. Schizophrenia bulletin, 5(1), 105-110.

Sümer, N., \& Güngör, D. (1999). Yetişkin bağlanma stilleri ölçeklerinin Türk örneklemi üzerinde psikometrik değerlendirmesi ve kültürlerarası bir karşılaştırma. Türk Psikoloji Dergisi, 14(43), 71-106. 
Tuğrul, C., Öztan, N., \& Kabakçı, E. (1993). Golombok-Rust cinsel doyum ölçeği'nin standardizasyon çalışması. Türk Psikiyatri Dergisi, 4(2), 83-88.

Uğur, K., Tamam, L., Özpoyraz, N., \& Demirkol, M. E. (2012). Bipolar bozuklukta özkıyım davranışlarının değerlendirilmesi. Cukurova Medical Journal, 44(2), 1-1.
Valentiner, D. P., Hiraoka, R., \& Skowronski, J. J. (2014). Borderline personality disorder features, self-verification, and committed relationships. Journal of Social and Clinical Psychology, 33(5), 463-480.

Yüksel, F.V., Kurt, A., Tüzer, V., Göka. E. (2004). Unipolar Mani. Klinik Psikiyatri. 7:161-166.

Zapf, J. L., Greiner, J., \& Carroll, J. (2008). Attachment styles and male sex addiction. Sexual Addiction \& Compulsivity, 15(2), 158-175. 